\section{Más cerca de la accesibilidad universal al patrimonio cultural}

La elección de Ávila por la Comisión Europea como Ciudad Europea Accesible 2011 en su primera edición pone de manifiesto el valor social del patrimonio como recurso para la integración. Resulta paradigmático que una ciudad Patrimonio de la Humanidad haya sido la primera en recibir este premio, así como que las otras tres finalistas hayan sido también ciudades con una fuerte componente patrimonial. Todo esto nos conduce a reflexionar sobre la relación entre accesibilidad y patrimonio.

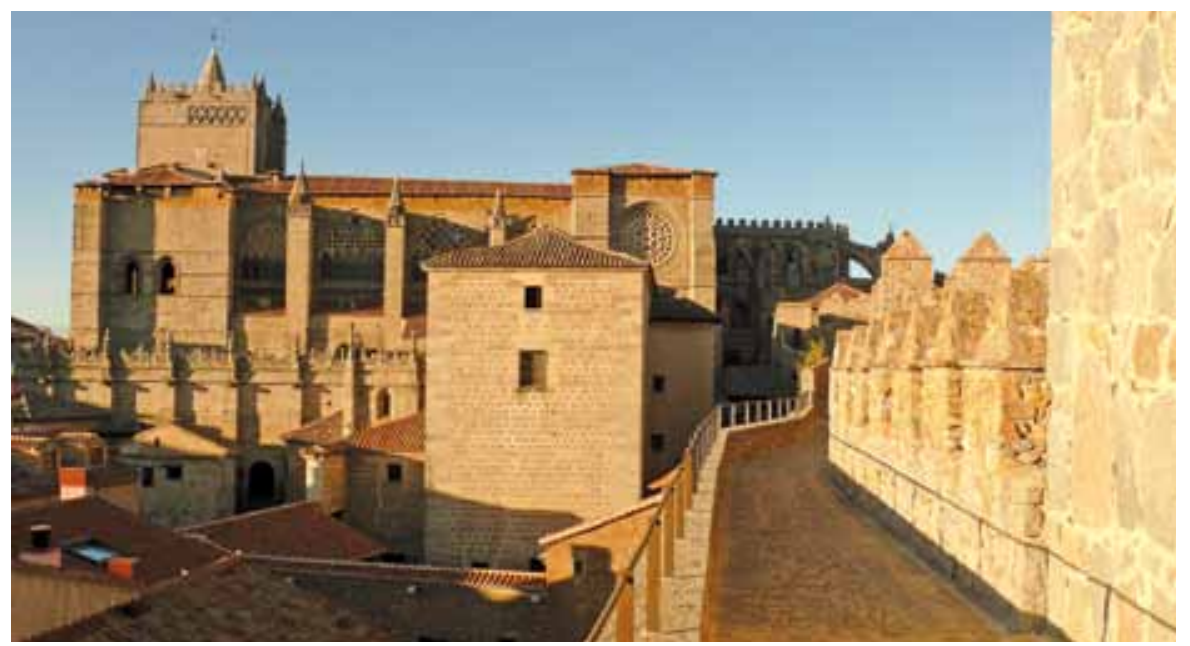

Paseo de la muralla de Ávila, actuación concreta para potenciar la accesibilidad. Foto: Joan Grífols

La accesibilidad al patrimonio es un caso particular del derecho de toda persona "a tomar parte libremente en la vida cultural de la comunidad", tal y como recoge la Declaración Universal de los Derechos Humanos (1948). Nuestra Constitución (1978) desarrolla este principio cuando enuncia que corresponde a los poderes públicos "promover las condiciones para que la libertad y la igualdad del individuo y de los grupos en que se integra sean reales y efectivas; remover los obstáculos que impidan o dificulten su plenitud y facilitar la participación de todos los ciudadanos en la vida política, económica, cultural y social".

Desde entonces se ha recorrido un camino en el que el concepto de accesibilidad ha abierto su ámbito de aplicación a los entornos, procesos, bienes, productos y servicios, ha incorporado nuevas prestaciones de tipo sensorial y cognitivo, y se ha hecho extensi- vo a todas las personas, llegando a definirse una accesibilidad universal, integradora y desapercibida. En paralelo, el patrimonio ha ampliado su escala al paisaje cultural, se ha enriquecido con los llamados patrimonios emergentes y se ha convertido en un recurso vivo, pasando a entenderse como una construcción social por la que las personas se identifican con determinados bienes del pasado que quieren disfrutar en el presente y conservar para el futuro. Desde estas premisas, resulta evidente que accesibilidad y patrimonio tienen en común su carácter dinámico y el interés por la persona como protagonista de la acción, ya que es ésta quien le atribuye los valores culturales a los bienes y establece a su vez las condiciones para su uso y disfrute.

Sin embargo, persiste la impresión de que son términos divergentes dada la dificultad de aplicación de la legislación vigente en materia de accesibilidad sobre espacios y edificios de interés patrimonial. Esto sucede porque la cuestión se plantea de un modo formalista y cuantitativo, basado en el cumplimiento estricto de unas soluciones estandarizadas, en muchos casos, no compatibles con los criterios de intervención en patrimonio. A pesar de las limitaciones implícitas en algunos bienes culturales por razón de su tipología o condiciones de uso, lo cierto es que la accesibilidad -en su sentido más amplioha sido siempre una condición inherente a los proyectos de conservación, puesta en valor, musealización y difusión del patrimonio: al descubrir un elemento oculto, crear escenarios de iluminación, trazar un itinerario, diseñar un sistema expositivo, ofrecer un servicio de visitas guiadas...

No basta con que la accesibilidad sea una medida a incorporar en la gestión e intervención de los bienes culturales sin afectar a sus valores patrimoniales -desde una especie de equilibrio entre la conservación del

\section{Accesibilidad y patrimonio} tienen en común su carácter dinámico y el interés por la persona como protagonista de la acción, ya que es ésta quien le atribuye los valores culturales a los bienes y establece a su vez las condiciones para su uso y disfrute

bien y las prestaciones a los usuarios- sino de que forme parte de las buenas prácticas. Afortunadamente estas cuestiones también comienzan a tener presencia en foros especializados como el reciente curso de formación del IAPH sobre accesibilidad universal e intervención en patrimonio cultural.

Aurora Villalobos Gómez, Departamento de Proyectos (Inmuebles, Obras e Infraestructuras) del IAPH 